\title{
PENGEMBANGAN BAHAN AJAR BERBASIS HASIL RISET LAPANGAN PADA GURU-GURU SOSIOLOGI DAN ANTROPOLOGI SMA SE-SURAKARTA
}

\author{
Saifuddin Zuhri ${ }^{1}$, Nurhadi ${ }^{2}$, Yosafat Hermawan Trinugraha ${ }^{3}$, Abdul Rahman ${ }^{4}$, \\ Sigit Pranawa $^{5}$, Okta Hadi Nurcahyono ${ }^{6}$, Septina Galih Pudyastuti ${ }^{7}$ \\ ${ }^{1234567}$ Universitas Sebelas Maret \\ Corresponding email: zuhri@staff.uns.ac.id
}

\begin{abstract}
ABSTRAK
Untuk meningkatkan kemampuan guru sosiologi di Kota Surakarta dalam hal pemanfataan teknologi pembelajaran serta pengembangan bahan ajar bagi peningkatan kualitas proses pembelajaran, grup riset Habitus mengadakan kegiatan pelatihan pengembangan bahan ajar berbasis hasil penelitian riset lapangan yang dilaksanakan pada hari selasa 28 Juli 2020 melalui pertemuan daring. Pelaksanaan kegiatan diisi dengan penyampaian materi terkait dengan Blended Leaning System dan Pengembangan bahan ajar berbasis penelitian. Dari hasil penelitian Riset Group kemudian dijadikan media dan sumber belajar baik secara visual maupun audio visual dengan sistem digital. Hasil dari pertemuan ini adanya luaran yang berupa website riset dari program studi pendidikan sosiologi antropologi FKIP UNS yang berisi hasil-hasil penelitian dari dosen dan mahasiswa serta video pembelajaran yang bisa dimanfaatkan sebagai bahan ajar bagi guru-guru sosiologi di Kota Surakarta.
\end{abstract}

Kata Kunci: bahan ajar, sosiologi, antropologi, dan hasil riset

DOI: https://dx.doi.org/10.20961/dedikasi.v2i2.45222

\section{PENDAHULUAN}

Perubahan adalah suatu hal yang tidak bisa terhidari dalam segala lini kehidupan, tidak terkecuali dengan pendidikan. Pada proses pendidikan perubahan terjadi dalam pendekatan pembelajaran, gaya mengajar, dan perubahan dalam pemanfaatan akses informasi (Watson, 2001). Tetapi relitanya perubahan yang terjadi dalam proses pendidikan selalu dikaitkan dengan fungsi simbolis teknologi dalam masyarakat. Maka dengan pendekatan yang konstrukstivis guru diminta adaptif terhadap perubahan, jika tidak akan tertinggal jauh dengan siswanya terutama dalam pemanfaatan teknologi.

Pada saat ini pemanfaatan TIK atau ICT dalam proses pembelajaran masih dipandang sebagai suatu bentuk inovasi. Padahal pemanfaatan teknologi informasi dan komunikasi (TIK) sudah menjadi praktik keseharian, dalam mempermudah kerja-kerja manusia. Terlebih pada generasi muda yang cenderung tidak akan lepas 
pemanfaatan TIK. Beberapa penelitian telah menunjukkan bahwa penerapan TIK mampu meningkatkan kompetensi dan kepuasan siswa dengan mata pelajaran yang dipelajari (Fillion, Limayem, Laferrière, \& Mantha, 2011; Hidayat, Hendrayana, \& Pujiastuti, 2018; Tabira \& Otieno, 2017; Tekos \& Solomonidou, 2009). Guru siswa harus siap untuk mengintegrasikan teknologi informasi dan komunikasi (TIK) ke dalam praktik belajar mengajar mereka di masa depan.

Fakta yang dijumpai dilapangan berbanding terbalik dengan harapan pada pembahasan sebelumnya. Banyak guru diantaranya masih kurang inovatif dalam proses pembelajaran. Hal ini ditandai misalnya dengan guru masih masih konvensional sehingga kurang menarik siswa dalam menerima pelajaran. Bentukbentuk bahan ajar konvensional tersebut antara lain buku teks pelajaran, buku teks sumbangan pemerintah, LKS yang dibeli melalui penyalur yang datang ke sekolahsekolah (Zuriah, Sunaryo, \& Yusuf, 2016). Meskipun peningkatan ketersediaan dan dukungan untuk integrasi TIK, relatif sedikit guru yang berniat untuk mengintegrasikan TIK ke dalam kegiatan pengajaran mereka (Ertmer, 2005). Selain itumasalah juga dihadpi oleh Mitra (MGMP Soiologi Surakarta), Banyak diantara mereka merasa kurangnya akses pengetahuan dan informasi terkait dengan perkembangan inovasi media pembelajaran berbasis ICT. Oleh sebab itu pentingnya pemanfaatan TIK dalam proses belajar, Sehingga mengajar bisa berjalan dengan baik.

Pemanfaatan TIK dalam proses pembelajaran dapat digunakan sebagai media pembelajaran atau bahan ajar, bahkan sebagai sumber belajar. Pada pembahasan ini cenderung lebih fokus pada pemanfaatan TIK sebagai bahan ajar. Banyak tulisan ilmiah yang mengenai pelatihan bahan ajar (Apriyanti, Raden, \& Rukiah, 2018; Listiawan, 2018; Siyamitri, 2015; Sopiah, Murdiono, Martha, Prabowo, \& Fitriana, 2019; Zuriah et al., 2016). Kesemua tulisan pada satu benang yang sama yakni meningkatnya kretaivitas guru dalam membuat bahan ajar sehingga tujuan pembelajaran dapat tercapai dan peningkatan kompetensi siswa.

Pada sisi yang lain, Program Studi Pendidikan Sosiologi Antropologi FKIP Universitas Sebelas Maret setiap tahunya memproduksi hasil-hasil penelitian lapangan, baik berupa skripsi mahasiswa, kuliah lapangan dan penelitian dosen. Kesemua penelitian tersebut kurang dapat dimanfaatkan oleh para mitra yakni para guru dan siswa. Hal ini menarik tim peneliti dari RG-Habitus untuk membuat sebuah sistem yang dapat mengintegrasikan penelitian-penelitian lapangan yang dihasilkan oleh Program Studi Pendidikan Sosiologi Antropologi sebagai bahan ajar dalam proses pembelajaran di sekolah.

\section{TUJUAN KEGIATAN}

Kegiatan pengabdian kepada masyarakat ini bertujuan untuk memberikan solusi dari permasalahan yang dihadapi kelompok guru Sosiologi SMA Kota Surakarta yang tergabung dalam Komunitas Musyarawah Guru Mata Pelajaran (MGMP) Sosiologi SMA Kota Surakarta, yaitu: 
1. Masih banyak guru yang memiliki latar belakang diluar bidang Sosiologi maupun Antropologi sehingga dalam proses pembelajaran menjadi kurang maksimal

2. Kurangnya akses pengetahuan dan informasi terkait dengan perkembangan inovasi media pembelajaran berbasis ICT.

3. Kurangnya kegiatan pelatihan dan pendampingan bagi para guru Sosiologi terkait kegiatan pemanfataan teknologi pembelajaran serta pengembangan bahan ajar bagi peningkatan kualitas proses pembelajaran.

4. Kurangnya antusiasme guru untuk mengikuti kegiatan pelatihan terkait beban mengajar ganda maupun tugas tambahan disekolah.

\section{PELAKSANAAN KEGIATAN}

Kegiatan pendampingan pengembangan bahan ajar ini dilaksanakan pada hari selasa tanggal 28 Juli 2020 melalui pertemuan daring. Peserta kegiatan merupakan anggota MGMP Sosiologi Kota Surakarta. Pelaksanaan kegiatan diisi dengan penyampaian materi terkait dengan blended learning system dan pentingnya riset dalam pengembangan bahan ajar.

\section{Blended Learning System}

Blended learning menjadi kebutuhan, saat ini, pendidikan saat ini mendadak menjadi pembelajaran digital karena adanya covid 19. Blended learning merupakan pembelajaran yang sederhana dan diharapkan dapat berkembang di Indonesia dan diharapkan dapat menjadi tantangan bagi guruguru sosiologi. Blended learning diharapkan dapat bertahap dan merata di Indonesia. Dengan hadirnya teknologi yang akan menjangkau sekolah-sekolah yang ada di Indonesia. Ketika berbicara tentang pengertian dari blended learning, ada dua komponen yaitu offline dan online, konsep blended learning adalah ketika pembelajaran offline digabung dengan pembelajaran online itulah yang disebut sebagai blended learning. Penggabungan berbagai keunggulan pembelajaran berbasis internet (e-learning online), berbasis multimedia (elearning offline) dan pemanfaatan teknologi mobile (mobile learning) dengan pembelajaran tatap muka (face-to-face) pada akhirnya diharapkan meningkatkan kreativitas peserta didik. Kreativitas menjadi sangat penting, oleh karena itu misi lembaga pendidikan adalah mendidik generasi bangsakelak menjadi manusia-manusia yang kreatif dan inovatif.

Pendidik/pengajar, baik itu pengajar ataupun dosen harus memiliki pengetahuan dan ketrampilan dalam menggunakan alat-alat dan sumbersumber digital untuk membantu peserta didikagar mencapai standar akademik.Menurut Kusairi dengan memasuki dunia online, pendidik/pengajar dapat memperoleh berbagai informasi yang diperlukan untuk memenuhi kebutuhan bahan pembelajaran. Teks, foto, video, animasi, dan simulasi adalah beberapa contoh media yang tersedia di situs-situs pembelajaran. Dengan 
memanfaatkan berbagai media tersebut, pendidik/pengajar dapat mempresentasikan konsep-konsep materi yang diajarkan dalam berbagai representasi (multiple representation) yang mempermudah peserta didik / pembelajar memahami sebuah konsep. Teknologi online juga memberikan kemudahan bagi peserta didik untuk mendapatkan tambahan informasi dalam rangka memenuhi tuntutan kompetensi dan juga pengayaan.

Di Indonesia untuk penerapan atau aplikasi blended learning yaitu: Edmodo, moodle, blackboard, successfactor, skillsoft. Ini adalah keseluruhan aplikasi berbasis internet. Axiology web binar ini adalah bahwa blended learning itu tepat, mudah, murah (masih kontroversial karena belum semua orang bisa mengakses), luas jangkauannya dengan segala kemudahan.

Awalnya, pemanfaatan blended learning sangat diunggulkan dibanding dengan pembelajaran konvensional secara tatap muka (face-to-face). Hal ini karena dengan blended learning, pembelajaran dapat lebih terbuka, fleksibel dan dapat terjadi kapan saja, di mana saja, dengan siapa saja. Intinya perkembangan ini mendorong perubahan paradigma pendidikan dari teacher centered learning menjadi student centered learning. Tetapi untuk mengarah kepada pelaksanaan 100\% blended learning, seringkali kesiapan SDM menjadi salah satu tantangannya. Masyarakat Indonesia seringkali mampu menyediakan infrastruktur, tetapi optimalisasi perangkat dan efek keberlanjutannya masih selalu dipertanyakan.

Setelah mempelajari beberapa literature, kita menemukan tiga bentuk transisi pembelajaran yaitu:

1. Full Conventional Learning sebagian dari orang luar jawa atau daerah terpencil belum bisa menerapkan bentuk transisi ini karena belum semua bisa mengakses internet.

2. Gabungan dari electronical dan conventional learning, bentuk transisi ini masih diperlukan pembuktian antara praktisi para guru yang ada di MGMP dan peneliti-peneliti yang ada di perguruan tinggi terkait dengan apakah pembelajaran blended learning dapat terlaksana dengan baik.

3. Full Electronical Learning, di Indonesia belum ada pembelajaran yang menggunakan full electronic learning.

Untuk kegiatan pengabdian masyarakat ini diharapkan ada output yaitu adanya bahan ajar dan adannya website pembelajaran, untuk bahan ajar ini terdiri dari media, silabus dan juga RPP. Sekarang proses belajar mengajar sangat dipengaruhi oleh media yang dipakai daripada guru atau murid. Silabus yang baku ada beberapa temuan best practice dari hasil riset untuk mempelajari bahan pokok pembelajaran.

Blended learning untuk saat ini yang sudah diterima adalah untuk media pembelajaran. Untuk saat ini ketika ada work from home pembelajaran kita lakukan dengan cara yang bervariasi. Untuk pembelajaran blended learning 
ada banyak pilihan media seperti youtube, google meet, zoom, instagram, facebook, email dll.

Jadi dapat kita simpulkan bahwa telah terjadi transformasi metode didalam pembelajaran yang semula dilaksanakan secara offline yang berupa: Baca teks, Ceramah, Tanya jawab, Tugas kelompok, Pekerjaan rumah menjadi metode online yang berupa: Baca cepat, Pengantar dan summary, Presentasi diskusi, Chatting, Group mentoring, Individual couching, Pengayaan mandiri.

Blended learning itu sebuah tantangan, blended learning itu sebuah kebutuhan, blended leaning itu sebuah harapan yang akan datang, jadi blended learning akan mewarnai suasana pembelajaran yang akan datang.

\section{Pengembangan bahan ajar berbasis penelitian}

Materi kedua dalam kegiatan ini menjelaskan tentang Pengembangan bahan ajar berbasis penelitian. Realitas yang terjadi saat ini adalah adanya suatu perubahan dalam sistem pendidikan, perubahan dari tatap muka ke arah interaksi dunia maya. Perlu adanya suatu proses adaptasi terhadap sesuatu yang baru dan selalu berpikir kritis. Diperlukan suatu strategi da;am kegiatan belajar mengajar agar dapat membantu mengurangi resiko penularan covid 19.

Hasil penelitian bisa menjadi bahan kuliah yang menarik (bersifat kekinian), karena berdasar pada data-data baru, maka hasil riset akan sangat relevan jika digunakan sebagai contoh-contoh kasus yang berhubungan dengan mata pelajaran (Sosiologi: pemberdayaan masyarakat, Perubahan sosial, perilaku menyimpang, gegar budaya atau integrasi masyarakat), akan menambah pengetahuan siswa, analisis siswa juga makin lebih tajam dan dalam, siswa akan mampu memahami persoalan secara lebih komprehensif.

Teknologi informasi mempunyai dua sisi dampak positif dan negatif.

Dampak positif yaitu:

1. Membantu kegiatan manusia, efisien dalam mengatasi jarak, ruang dan waktu,

2. Mempercepat arus informaasi dari berbagai sumber,

3. Memudahkan kita dalam mengakses data dan informasi sesuai dengan kebutuhan Pengembangan bahan ajar,

4. Memanfaatkan hasil-hasli penelitian yang bisa diakses di dunia maya

5. Di tengah kondisi pandemic covid 19 ini, juga berdampak pada cara belajar pada umumnya, dari offline menjadi online.

6. Memanfaatkan materi yang sama untuk kelas selanjutnya dengan modifikasi agar lebih menarik (bagi pengajar)

7. Bisa memutar kembali bahan yang belum dipahami melalui rekaman (bagi siswa)

8. Membuka peluang kerja dengan memanfaatkan teknologi untuk memperoleh pendapatan, termasuk dalam bidang pendidikan 
Dampak negatif, yaitu:

1. Mendorong terjadinya penyimpangan

2. Merubah pola interaksi: melunturnya gotong royong dan sopan santun

3. Mengurangi minat baca dan pendalaman materi

4. Mengurangi disiplin dalam berpakaian dan belajar

5. Mendorong plagiarism

6. Mempersulit penilaian obyektif dalam pembelajaran online

Beberapa faktor pendorong perubahan

1. Pemikiran (penemuan baru atau inovasi baru)

2. Materi (teknologi dan ekonomi)

3. Konflik

4. Interaksi

5. Demografis

6. Bencana (pandemic corona telah merubah dari sesuatu yang lama (kebiasaan), menuju kebiasaan baru/pada sesuatu yang baru).

\section{PENUTUP}

Untuk membuat bahan ajar diperlukan sebuah Road map pengembangan bahan ajar. Dalam situasi terkini dengan adanya pandemic ini maka pembelajaran blended learning menjadi penting untuk dilakukan.

Hasil dari pertemuan ini adanya luaran yang berupa website riset dari program studi pendidikan sosiologi antropologi FKIP UNS yang berisi hasil-hasil penelitian dari dosen dan mahasiswa serta video pembelajaran yang bisa dimanfaatkan sebagai bahan ajar bagi guru-guru sosiologi di Kota Surakarta.

\section{DAFTAR PUSTAKA}

Apriyanti, M. E., Raden, A. Z. M., \& Rukiah, Y. (2018). Membuat Bahan Ajar dengan Teknik Transfer Laser Print bagi Guru-guru. Jurnal PkM Pengabdian $\begin{array}{lll}\text { Kepada } & \text { Masyarakat, } & 20 .\end{array}$ https://doi.org/10.30998/jurnalpkm.v1i01.2357

Fillion, G., Limayem, M., Laferrière, T., \& Mantha, R. (2011). Integrating ICT into Higher Education. International Journal of Web-Based Learning and Teaching Technologies, 3(2), 48-72. https://doi.org/10.4018/jwltt.2008040104

Hidayat, S., Hendrayana, A., \& Pujiastuti, H. (2018). Identification of Readiness of Developing University to Apply Information and Communication Technology (ICT) in Teaching and Learning. SHS Web of Conferences, 42, 00117. https://doi.org/10.1051/shsconf/20184200117

Listiawan, I. (2018). Pelatihan Pembuatan Tutorial Untuk Pengkayaan Bahan Ajar Guru SD Taman Muda Ibu Pawiyatan Yogyakarta. 1(1), 1-4.

Siyamitri, P. (2015). Literasi Media Internet pada Kalangan Guru Sekolah 
Menengah Kejuruan di Kota Medan. Jurnal Simbolika/Volume 1/Nomor 2/September 2015, 1(September), 161-176.

Sopiah, Murdiono, A., Martha, J. A., Prabowo, S. H. W., \& Fitriana. (2019). Pelatihan dan Pendampingan Penyusunan Bahan Ajar Bagi Guru SMA 5 Kediri. Karinov, 2(1), 52-56.

Tabira, Y., \& Otieno, F. X. (2017). Integration and implementation of sustainable ICT-based education in developing countries: low-cost, en masse methodology in Kenya. Sustainability Science, 12(2), 221-234. https://doi.org/10.1007/s11625-017-0422-8

Tekos, G., \& Solomonidou, C. (2009). Constructivist learning and teaching of optics concepts using ICT tools in Greek primary school: A pilot study. Journal of Science Education and Technology, 18(5), 415-428. https://doi.org/10.1007/s10956-009-9158-2

Watson, D.M. Pedagogy before Technology: Re-thinking the Relationship between ICT and Teaching. Education and Information Technologies 6, 251-266 (2001). https://doi.org/10.1023/A:1012976702296

Zuriah, N., Sunaryo, H., \& Yusuf, N. (2016). IbM GURU DALAM PENGEMBANGAN BAHAN AJAR KREATIF INOVATIF BERBASIS POTENSI LOKAL. Dedikasi, 13, 39-49. Retrieved from 1693-3214 